\title{
THE ROLE AND UTILITY OF MILITARY POWER
}

\author{
Col A. van Driel*
}

\begin{abstract}
Introduction
Political and especially economic blocs of power and internal trends of individual states towards welfare have drastically changed international politics. The destructive power of nuclear weapons cannot be ignored, while the other pole namely the vulnerability of states to insurgency/subversion is equally prominent and threatening. Characteristic of modern times is, inter alia, the participation of more actors in world politics. The overwhelming influence of the three nonEuropean states, namely the U.S.A., U.S.S.R. and Red China, plays an equally important role in the concept of strategy for the rest of the world community. Against this background and in the light of the Conceptional background, the present-day usefulness of military force, as an instrument of total strategy, is critically examined. ${ }^{1}$
\end{abstract}

\section{Aim and scope}

\section{Aim}

The purpose of this article is to determine whether any change of emphasis in the role and use of military force by a state can be detected during the last two decades, and what the resultant problems associated with international conflicts are - the importance of new trends to Southern Africa.

\section{Scope}

Due to the complexity of the subject, the scope of the article, besides the conceptional background, will make provision for the following:

\section{- Background}

- The general validity of the idea that violence is no longer a valid means to solve international conflicts.

- Why the foregoing statement is supported by so many authorities.

- Relation of above-mentioned with the concept of limited war.

- The role played by military power in Southern Africa.

\section{Military power}

\section{Background}

In conjunction with the introductory part, the influence of nuclear weapons should be looked at in greater detail. Holsti points out that all weapons are ethically neutral, but that the potential role or aim of application should be judged from an ethical point of view. Nuclear weapons have had far-reaching consequences on many aspects of warfare, quite apart from the destructive aspect. Schelling declared that nuclear weapons can change the speed, control and sequence of events, as well as the relationship of the victor towards the vanquished; furthermore the relationship of homeland (launching point) towards the battle zone (target country). Time and space, which were the previous corner-stones of protection/defence, have at present the opposite meaning, due to the influence of nuclear technology on weaponry.

International relations are further characterized by calculated risks. Arms control such as the SALT I and II agreements between the two superpowers have become necessary to curb the arms race and to ensure relative stability. Bernard Brodie declares that nuclear stability is obtained when every state believes that the advantage of a 'first strike' is overshadowed by the tremendous costs involved. In this way a stalemate situation exists, as a nuclear war will be out of all proportion to any political objective. What then of the other big and medium powers, when the majority do not possess nuclear weapons? The military forces of developed Western nations display chiefly the following characteristics:

- Smaller military forces on a volunteer basis.

- Good liaison and interaction with civilian specialists.

- Young leadership elements.

- Open systems in order to ensure the trust of the population (electorate).

Finally, the strategic problems arising from nuclear technology must be referred to briefly. Apart from financing, the choice of strategy and doctrines as well as their combination plays a big role. A further grey area in the application of nuclear weapons is the expected speed of decision-making processes and consequently the high demands which can be placed on decisionmakers. 


\section{The utility of violence to settle disputes}

At the outset it should be pointed out that military power in the existing cultural environment and time span has in its widest sense, the objective to influence attitudes of political and military decision-makers. In this respect the definition from UNISA sources, with reference to 'operational strategy' in a military context, may be quoted: '.. the way in which a military force, which has specifically been assigned to bring about a particular military situation which will persuade the enemy commander to surrender without resistance, or, if a clash does in fact occur, that it would mean their having to submit or suffer unacceptable losses.' The latter definition implies not only constraint instead of violence, but also alludes to Liddell-Hart's strategy of indirect approach; the indirect approach has a geographi$\mathrm{cal}$ and manoeuvering connotation where military force is employed.

Knorr identifies certain obstacles in the course of an attempt to determine the value of military power, which will be mentioned for the sake of clarity and for purpose of objectivity. He indicates that general answers would be vague and superficial and that preference should be given to specific problems; that the complexity of the problem and the use of military power may originate from a broad series of values and interests; and finally that usefulness is relative to value and it is not measurable. In practice the utility of military power to a state is threedimensional, viz the use of international war, that of military threats and that of the mere possession of military power.

The application of violence (military force) in the context of deterrence/defence points to the failure of military power as a deterrent. When military power is therefore used as a deterrent, its role changes according to the hierarchy of the usefulness as such. By implication the role of 'mere possession' changes to military threats, then to war in some form or other. These transitional stages may occur due to failures of previous dimensions, or to an escalation of violence. These dimensions, as set out, constitute a usable theory for the prevention of war. The two world wars are examples of instances in which this theory was ignored with regard to the concept of 'total violence' which is the perception of the misled exponents of Clausewitz ${ }^{2}$.

Schelling approaches the problem more critically when he contrasts blatant violence with 'coer- cion.' He concludes with the statement: 'It is the difference between the unilateral, 'undiplomatic' recourse to strength, and coercive diplomacy based on the power to hurt.' In this way the writer confirms the theory that military power can be a deterrent - to this he adds the desire to hurt, as well as the credibility of the threat. Furthermore, he illustrates by means of examples, the uselessness of destruction and extermination, eg the extermination of Red Indians in the USA, the German/French battle at Verdun and the methods of Genghis Khan ${ }^{3}$. These views of Schelling may suffice provisionally.

As has already been mentioned in the introduction, welfare and economic trends in capitalistic states prevailed over security problems in the seventies. Democratically elected governments started having serious doubts about military power, mainly on account of economical and internal party - political reasons. The results of economic interdependence of capitalist states were cultural (severe criticism of the Protestant ethics and values), and political (inclination towards genuine democracy or liberalism as opposed to traditionally formal democracy). This preceding change of attitude subjected governments to greater internal political pressure, vis-á-vis the demands for the preservation of a high standard of living for its electorate.

It now becomes clearer why Governments of capitalist countries are primarily economically orientated. Internal economic problems and party - political pressures, by pressure groups on a government, are inclined to have the effect of causing security aspects to be overlooked in favour of establishing a policy of internal welfare. The perception of a military threat has abated in capitalist countries - instead, economic crises, due to interdependence (eg oil), are regarded as security problems. Likewise, concern about national security is observed when vital national values are threatened by negative foreign action. The latter threat must be visual and/or physical.

The general view that conventional forces have apparently become useless and superfluous due to nuclear weapons, cannot be sustained. The accent is on 'apparently'. The deductive argument with regard to no nuclear conflict since the Second World War, does not support the preceding view. The critical view centres rather on the role of military power, the value and extent thereof against the background of contemporary international political trends. 
In conclusion, a synopsis of important aspects is expounded. Obstacles in the analysis of the value of military power, as formulated by Knorr, must still be guarded against. In the present decade military power must constantly influence the attitudes of governments and decision-makers. The use still remains three-dimensional, with the accent on 'threatening' analogical towards the employment of sustained military coercion in a continuous conflict situation. Failures in the traditional use and role of military power are seen, in the modern context, rather in the application of the third dimension, viz war, or overt and direct violence. Schelling is an exponent of coercion instead of violence, although sustained coercion in the modern context tends to a situation of continuous military threats. Security must be fundamentally threatened (for reaction) in a modern Western capitalist system which is primarily based on economic welfare and internal politics, notwithstanding the paradox of international economic interdependence. The change of emphasis towards the useful role of military power is due to the fact that it has changed to 'threatening' since about 1970. This conclusion must be seen particularly in the context of conventional war in a world of artificial peace; limited conflicts continue. Finally, military power must be seen as a control measure in a situation of permanent coercion.

\section{Points of view of authorities on the changing role of violence}

Buchan's familiar 'costs vs gains' proposition implying political or military costs (damage) against expected political or military gains or benefits is important in this context: 'As strategy of deterrence is intended to prevent actions which prejudice one's own interests by threatening the opponent with losses which could outweigh any gains he might expect by taking them'. ${ }^{4} \mathrm{He}$ indicates a credible threat against the potential aggressor in order to prevent him from employing his military capability. Stanley Hoffman refers to the decreasing acceptability of violence in liberal Western democracies; at the same time he points out situations where a feeling of being threatened is still prominent. He specifically mentions Switzerland and Israel, but the pronouncements of political leaders in the RSA puts South Africa in this category as well.

Hoffman enlarges on the above-mentioned aspects. 'There is a risk of a world divided into two different ages and zones...' His findings are subsequently summarized. In one zone domestic priorities, etc, will lead to an 'unleashing' of the use of overt military violence whilst in the other (the rest of the world) traditional international relations and conflict risks will persist and armies (sic military power) will still play a prominent role in conflicts. A dilemma has arisen here (in world politics) of self-sufficiency which can lead to pacifism, as seen against the trend to excessive arming (hyper-assurance) which may result in great international risks. The solution proposed by Hoffman is 'military reforms'. The latter solution may be dualistic, viz a highly specialised voluntary military force ('mobile force - in-being'), or de Tocqueville's idea of a people's defence force. The nation (people) must be mature for a national defence force and have an understanding of a genuine threat - such as the authorities in the RSA, Isreal and Switzerland are experiencing at present. Inevitably the perception by the nation, of a threat, is not always in accordance with what is observed by the government. A final remark in this connection is the paradox between the acceptability and the necessity of the use of military violence; supplementary hereto is the concept of the necessity or not for military preparedness.

The theories of Schelling further support the argument of 'threats' rather than violence: ' . . . an era in which the power to hurt is more impressive than the power to oppose'. In addition he describes a theory of risk manipulation ('brinkmanship') $)^{5}-$ his analogy of mountaineers in pairs suitably illustrates this concept; his definition on 'the manipulation of the shared risk of war' elucidates the concept. For the purpose of this essay the emphasis should be on Schelling's key concepts, viz threat, uncertainty and credibility.

We will pause a while with the theories, convictions and philosophy of the military leaders of the RSA. Deterrence as such is dependent mainly on the ability to prevent the decisionmakers of the target country from deciding to employ their military instruments against the ego state. The main elements on which this ability depends are a military ability, credibility in the employment thereof and clear interstate communication. ${ }^{6}$ Credibility is determined by effective striking-power, the potential of a defence force to maintain and strengthen its ability and thirdly the respect for a state's acknowledged willingness to firmly employ its military strikingpower. ${ }^{7}$ In a climate of militant and revolutionary threats (as in Southern Africa at present) a country is forced to maintain a sustained threatening military posture. The impact of these threats lies in the will and 
ability to convert them into deeds.

Although Martin's essay is concerned with the use of usefulness of military force, his findings nevertheless imply the matters of acceptability and relative role fulfilment. He uses the syllogism that low usefulness can cause the acceptability to fade, and that low acceptability can reduce the usefulness and consequently be a costly undertaking politically. Martin supports Hoffman's view of the dilemma in which Western democracies find themselves. Martin declares that since the Second World War there has been a recognition of the futility of war (force) in the industrialized countries. In addition, he refers to the revision of the perceived relation between military means and political objectives brought about by nuclear weapons. This view quite paradoxically boils down to the well-known Clausewitzian concept of 'war is nothing but a continuation of political intercourse ... policy itself, which takes up the sword in place of the pen.' In other words, the paralogism of 'total force' (which is Clausewitzian) concerning the two world wars, is now contradicted, as Clausewitz has recognized the close connection between political objectives and military means and theorized about it. ${ }^{8}$

A summary of Martin's findings deserves more attention. The strategic balance of power (stalemate) in nuclear weapons has merely brought about an 'uncomfortable peace'. The extent of the effect of nuclear deterrence must be supplemented by other military capabilities. If military violence were to remain useful it would be restricted at all levels and would exercise its influence in a typically latent manner (in accordance with Schelling's point of view). Persuasion will play a bigger role. In view of its more flexible employment as an instrument of foreign policy (which must be subtly orchestrated) it is more difficult for the armed forces to explain their role. Obsolete 'scenarios' by governments in the Western World, such as regarding defence as an 'insurance policy', must make way for the retention of the ability to maintain security in times of crises, in the face of a feeling of complacency.

Weltmann concludes his article on the obsolescence of war as follows: 'We should not easily assume that we will avoid the consequences of pluralism ...' From this can be deducted that the existence of a plurality of states (as identified also by Buchan), per sé the international system, can lead to conflicts. A plurality of states, however, also implies a plurality of national interests that can lead to conflict. As the causes of war in itself constitute an extended study, we will content ourselves with this thought. In this context we may briefly refer to international economic interdependence and how the internal trends towards welfare can undermine the national will to resist.

National will may be defined as: ' . . the ability of national authorities to commit regulatory and allocative powers to national programmes of action designed to cope with external events that affect national security, whether economic or military'. The national will is harmed not only by differences in perception of the threat, but when deep-seated differences exist regarding the best course of action to be followed to resist a threat. Government leaders must display ingenuity in organizing support for their policy. The dual dilemma of democracy is, firstly the way in which interest groups are integrated in the national political system with their distinctive support for national authorities; secondly, the extent of which the citizens offer resistance to the mobilization of national resources for security programmes, in favour of short-term advantages and by faulty insight into the international political system.

In summary, the following key concepts may be identified. A credible threat must exist against potential aggressors. Credibility is characterized, inter alia, by the will to employ force, and is supported by 'brinkmanship', which eliminates wilfulness. The threat must display the will and ability to employ force and thus instil fear iro violence as well as uncertainty among enemies (Buchan's 'cost vs gains'). In spite of the declining acceptability of violence, due to an unobtrusive threatening milieu, the inherent results of the international community of nations vis-á-vis conflicting interests cannot be evaded. Conflict will continue. The two zones are characterized by complacency concerning national security, and by traditional conflict. As a result of the latter zone, security awareness is an important manifestation in the present decade. Military reforms are essential particularly where the threat is not overtly perceptible. The latter is also responsible for the undermining of the national will. This is due to a general apathy among voters (citizens) in democracies, to sacrifice their personal short-term objectives to the advantage of national security (and interest). The latent violence of military power is thus emphasized in playing another role, viz threat, to control potential enemies. 


\section{Limited warfare - the coherence}

As a point of departure, Gen J. F. C. Fuller's definition of limited war is used: '. . . a war fought for a clearly defined limited political object, in which expenditure of force is proportioned to the aim ...' Mainly one characteristic, viz deliberate restraint of certain available means, distinguishes limited war from unlimited war.

The concepts of limited war, revolutionary war and indirect onslaught have taken root, due mainly to the nuclear stalemate. These concepts centre chiefly on domestic interest of national security. In the interest of reievance, attention is confined in this part of the essay to limited war and the coherence with the threat of violence. Although this concept became better known after the Second World War, mainly to exclude nuclear weapon employment, it has since undergone a transformation.

At present, both nuclear war and conventional war may be limited/unlimited. When the political objectives are overlooked, the tendency would exist to measure limited war in terms of military objectives, amount of violence and geographical area involved. Conventional war is often measured by the degree of destruction of property/lives.

If, however, Gen Fuller's definition is approached analytically, one realizes that limited war is relative. The relativity lies in the exercise of violence in relation to the political objective - this objective may, however, comprise a limited or wide spectrum. In this context the two world wars may be described as total war (despite the limited participation of some states), as against a limited Korean War. The contemporary milieu is characterized by the absence of declarations of war per sé. It goes hand in hand with limited conventional onslaughts or revolutionary war. In the former case escalation is relatively easily limited, but in the latter case escalation is characteristic of a long drawn-out struggle of low intensity. In this connection USA involvement in Vietnam serves as an example. Any escalation in violence is destabilizing and therefore unacceptable to Western society. In view of the aforegoing, the limitation of violence and limited war are actually concepts that are reconcilable. Martin surveys the possibility of Western intervention in the Third World - he comes to the conclusion that besides a decrease in the ideological power struggle and declining Western trading interests in the Third World, (comment: this situation has somewhat changed within the last four or five years); greater trust at present exists regarding non-military methods of conflict in attaining objectives.

No country has at present an unlimited potential for war at its disposal (ability to conduct a prolonged struggle); the developed countries, however, all have a military potential (ability to conduct limited military actions). The world order has not experienced nuclear war since the Second World War (except for Nagasaki and Hiroshima). The period since has also been characterized by limited conventional onslaughts that lasted for days/weeks/months or even longer. In this context, the two most recent Arab-Israeli Wars, the Vietnam War, India/Pakistan, the Angolan Civil War (1975-6) and the Belgian/French rescue attempt in Shaba (Zaire) in 1978 may be referred to. The longest of these was the Vietnam War, while the Angolan Civil War lasted a mere five months, seen from a semi-conventional point of view. All of the above-mentioned wars had specific limited objectives.

As far as military means and political objectives are concerned these aspects are clearly set out in Osgood's book: 'Limited War. ..' Although the work mentioned was published in 1957, his formulation of the concept is still regarded as relevant to this day. Osgood regards intelligent and vigilant political control as a prerequisite for the use of military violence : '. . . for when military policy and strategy lack the guideposts of limited and attainable objectives and become in effect ends in themselves, they cease to be controllable and predictable instruments of national policy'. $\mathrm{He}$ proceeds in detail to set out the limited political objectives of the Korean War; notice, by contrast, Gen McArthur's view and dismissal from his post. This foregoing view confirms the exposition of direct and indirect strategy. The direct modus chiefly makes use of military conflict methods, while the indirect methods concentrate on political, economic and diplomatic coercion, with a menacing military posture in the background. The latter modus operandi of total strategy operates more in the psychological sphere, in other words, the breaking down of the opponent's will to resist, or at any rate of that of his decision-makers.

The foregoing exposition of limited war confirms Henry Kissinger's contribution. In his 'Necessity for Choice' he consequently gives three prerequisites for a strategy of limited war:

- Limited military forces must be able to prevent the potential aggressor from establishing a fait 


\section{accompli'.}

- Conflicting parties must be able to co-ordinate with diplomatic means which will be successful in persuading that total war is not the only answer to conflict. Mutual willingness must open the road to settlement negotiations.

- If limited military forces of the free world can easily be overwhelmed, aggression or blackmail will be encouraged. The potential enemy must not interpret limited war as the prelude to full-scale war.

In a summary of the relation between limited war and the question of the use of violence, the following aspects are relevant. The fact that violence stands in a direct relation to political objectives, continues to indicate limitations to minimum force. Deliberate restraint of certain means is an important aspect of strategy. Security aimed at the maintenance of a status quo is characterized by threats of violence, in other words by deterrence. The political objective must constantly be kept in mind. Although an absence of formal declarations of war can result in escalations, they are in fact conducive to the employment of limited violence and means. Should escalations follow the initiating of violen$\mathrm{ce}$, it becomes unacceptable to the Westerner. The manipulation of escalation is of greater importance than the negation thereof. Likewise, Western powers would rather settle disputes in the Third World by making use of non-military conflict methods. Unrestricted violence and full-scale war are either impossible or limited in terms of the economy of a country. Since the Second World War violence has been characterized mainly by limited conventional wars for specific political purposes. Only rational political objectives that are to be achieved by force, are a predictable instrument of national policy. The danger of escalation is one of the main reasons why the limited war strategy has a deterrent effect.

\section{SOUTHERN AFRICA}

\section{Introduction}

The states in Africa and Southern Africa in particular belong to the second zone according to Hoffman's theory. This is the zone where conflict is still a dominating characteristic of international politics. This subcontinent is plagued by terrorism. ${ }^{9}$ The revolutionary war in South-West Africa has already been raging for several years. There is little doubt that this threatening milieu is real.
The majority of inhabitants, especially Whites of the target countries and others involved, accept the view of their government that defence is necessary. The violence of terrorists against defenceless citizens is unacceptable.

The revolutionary wars are encouraged in so far as their perpetrators obtain financial aid and weapons from communist countries, as well as from the World Council of Churches (WCC) and from some capitalist countries. In addition, the host countries harbour the terrorists in their territories adjacent to the target countries. By means of the forum of the United Nations (UN) and due to a strong African/Arab bloc, they succeed in obtaining a measure of international recognition and sanction (in the guise of 'freedom fighters'). In this way the General Assembly of the UN recognized the 'South-West Africa Peoples Organization' (SWAPO) as the sole representative of South-West Africa (SWA) early in the SWA constitutional process of development towards independence. Due to this action of the UN the RSA government and SWA administration find themselves in an unenviable position. Participation in the democratic political processes is thwarted and delayed by SWAPO, probably in the hope that the delays will benefit them. In the same way SWAPO maintains a posture of aloofness in the settlement efforts (based on UN Resolution 435) being negotiated at present by the RSA/SWA and the Five Western Powers. The latter course is pursued in such a manner that a long drawn-out struggle of low intensity may aggrieve the government of the RSA, while SWAPO entertains the hope that public opinion in the territory will turn in its favour. So much, at present, for the insurgency threat.

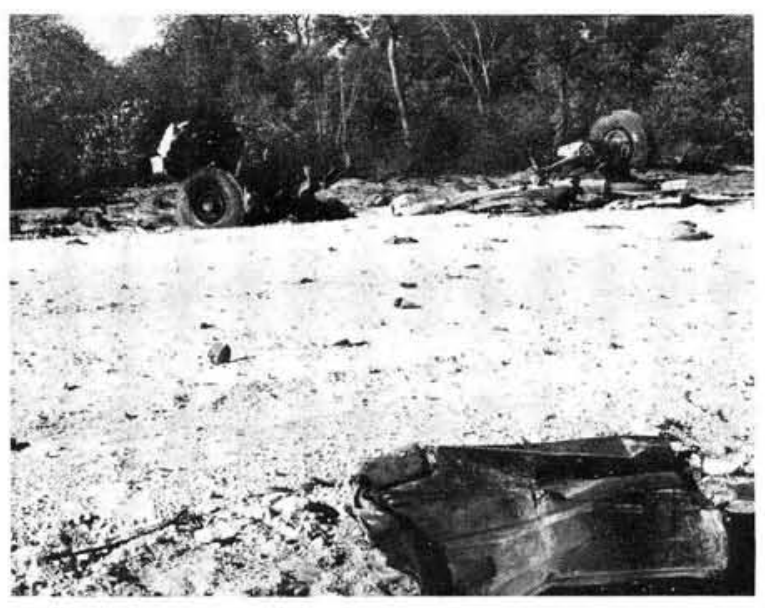

All that has remained of a vehicle belonging to members of the local population of Owambo after having been hit by a land mine, can be seen on this photograph. In this specific instance seventeen people were killed. 


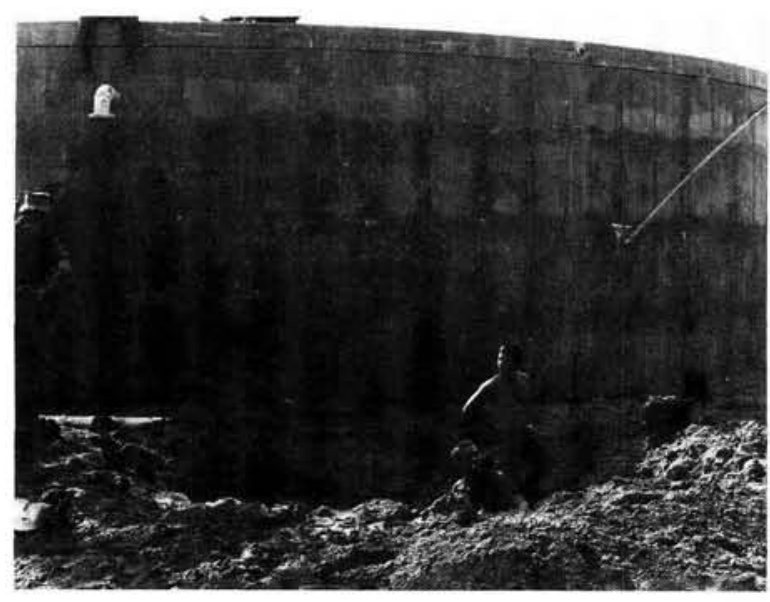

Sabotage of water supply installations is one of the favourite objectives of SWAPO terrorists. The Defence Force is often required to intervene in order to restore the supply of water to man and animal in Owambo.

\section{The environment of threat in the RSA}

The Honourable Minister of Defence, Gen Magnus Malan, identified the elements of our environment of threat as follows:

- The Cape sea-route.

- The ideological connections of the RSA with our Western friends.

- Misconceptions concerning our national objective of multinational development.

- The influence of internal conditions and race relations.

The Cape sea-route may rightfully be regarded as the life-artery for the trade of the free Western World. The strategic importance of this seaway is not contested by strategists in the West, and can hardly be over-emphasized. ${ }^{10}$ The ideological struggle for power between Communism and Capitalism places the RSA in the battleground of their dialectics. Despite the strong stand taken by the RSA government against the communist ideology, the West cramps the RSA with arms embargoes. Ironically, however, the RSA, as part of the subcontinent of Africa, has to ensure its future and continued existence here at the southern tip of Africa.

Multinational development is exploited by radical elements in an effort to prove that it is an attempt by the white government to wrong the black majority. The RSA government's policy and actions are the opposite, however, viz to lead all the nations to independence. Lastly, the RSA's racial situation lends itself to incongruencies in practically every field. Inequality is exploited by radicals who convert it into distorted propaganda, which could internally give rise to offence, misunderstanding etc on account of poor discretion.

It is therefore not surprising that the RSA is extremely vulnerable to bringing the wrath of Black Africa upon itself. Militant African states often loudly proclaim the so-called liberation of their black brothers in the RSA by means of armed conflict; this 'liberation' would be, according to their interpretation, a freeing of the yoke of white domination. In this way the RSA finds that its policy of self-determination is misinterpreted in a large part of Africa. The truth is that militancy against the RSA arises from the adolescence of revolutionary black nationalism and from the recent movement towards independence in states in Southern Africa that have obtained independence through violence. By contrast, National States that have obtained independence from the RSA, develop harmoniously and are occupied with the development of their economies and not with an a priori polarisation of Black and White.

\section{Africa}

As has been briefly referred to, Africa has undergone a political transformation since the fifties. In the two decades $1950 / 60$, some fifty newly independent Black States came into being due to the decolonisation process. These new states lost the protective umbrella of their former European guardians and thus did not have the necessary defence mechanisms. African states, therefore, had to depend on individual or collective ingenuity and political acumen in order to remain standing in a world of competing power blocs.

In order to understand the foregoing exposition better and to bring African politics into perspective, OAU policy must be examined. Three important policy directions towards foreign countries are referred to in this context:

- Inter-African solidarity.

- Strong links with Asian and Arab states.

- Politicisation of international affairs, particularly decolonisation, with the aim of calling to account the conscience of the West.

As a result of the afore-mentioned policy, it is inevitable that militants in Africa would like to brand the RSA as the scapegoat, being the only dominantly white government in Africa. Africa and Russia openly propagate the 'one man, one vote' idea. The South African government also sup- 
ports the one man one vote idea, but on the basis of separate voters' rolls based on the policy of National States and self-determination, which is founded on multinationalism.

\section{Strategic importance of the RSA}

The strategic importance of the RSA is due to two extremely important facts, viz its position with regard to the Indian Ocean and the Cape sea-route; secondly its extensive mineral riches, particularly its strategic raw materials. ${ }^{11}$ These two facets will be briefly enlarged upon. Before this matter is dealt with in further detail, brief reference will be made to the irony of the importance of the RSA and Africa to the superpowers, who compete on an unprecedented scale to get Black Africa within their sphere of influence, inter alia by means of foreign aid programmes. This forms a contrast with their techniques for dealing with the RSA. The attitude of the Russians towards the RSA itself is self-explanatory, due to the latter's openly declared anti-communist policy. Their motivation is probably augmented by their regarding the mineral riches of the RSA as more accessible under a Black Majority regime.

The importance of the Cape sea-route will now be discussed briefly, as it is closely linked to the security of the RSA and the use of military power. The Cape sea-route joins the two great oceans on opposite sides of Africa, viz the South Atlantic Ocean along the west coast and the Indian Ocean along the east coast. The latter was declared a 'zone of peace' by a UN resolution, but this will not deter the Russians from activities aimed at displaying their power on account of their political prestige among certain east-coast states of Africa. Except for the USA's abortive attempt to establish a naval base at Diego Garcia, very little has yet been done by them to neutralize Russian influence in this area of the ocean. ${ }^{12}$ This situation prevails despite the fact that sixty per cent of the oil destined for Europe and fifteen per cent of the oil destined for the USA was transported via this route as recently as 1978 . These large quantities of oil may possibly have decreased since the Iranian revolution. Preparedness and vigilance must be emphasized, as well as a threatening attitude to discourage adventuristic action along this life-artery of the West.

The RSA is well-endowed with strategic raw materials, except oil. As the RSA is selfsupporting in most respects, the situation is ironical, since South Africa's riches constitute an attractive bait for her opponents. As far as copper is concerned, the RSA satisfies its own requirements; in 1971 the RSA was already producing eighty-seven per cent of the iron-ore on the African continent; uranium (a by-product in the extraction of gold from gold-ore) is necessary for nuclear energy - the RSA is the third largest uranium producer. In addition, the RSA is at present the largest producer of platinum-group metals in the world. Manganese deposits are sufficient for the RSA for nearly five centuries; the RSA is the third largest asbestos producer in the world. The RSA does not only have the largest chromium reserves in the world, but is also the most prominent producer of vanadium. The RSA is dependent on oil for nearly twenty per cent of its energy requirements, while for some industrialised countries oil has to satisfy fifty per cent of their energy needs. The massive reserves of low-grade and cheaply-exploitable coal in the RSA has, since the energy-crises, aided it in making it less dependent on crude oil. It is expected that with the inauguration of SASOL III, it will be able to satisfy as much as fifty per cent of the fuel requirements of the RSA. ${ }^{13}$

The RSA produces nearly sixty-five per cent of the world's and seventy-seven per cent of the non-communist world's gold. There can be no doubt that it is a major asset to the RSA, particularly as seen in the light of favourable gold prices over the past few years (despite the recent down-swing in prices on the world market). Gold ensures a favourable trade balance for the RSA.

\section{A strong economy}

The economy of the RSA has experienced unprecedented growth in the most recent decades, ie since becoming a republic. This is due to political stability. But above all, a strong economy was necessary to make the country militarily prepared and defensible. While the RSA covers only four per cent of the land area of Africa, it is responsible for nearly twenty-four per cent of Africa's total production. The RSA therefore has the economic power and ability to be militarily prepared, and can make suitable use of this instrument of coercion and threat. In this connection the Bible may serve as an analogy: 'He drove out the man; and at the east of the garden of Eden he placed the cherubim, and a flaming sword which turned every way, to guard the way to the tree of life'. ${ }^{14}$ (Gen 3:24). Likewise the Defence Force of the RSA must protect and guard the country's national interests with the sword that flames and flickers - a means of 
coercion per sé.

\section{General}

In conclusion, the RSA's milieu of threat must be seen against the background of its internal policy on the one hand, and its reliable economic power on the other. It has an internal policy which is realistic and formulated as the foundation of a rational, national strategy, and is aimed at eliminating racial discrimination and leading the black nations to self-determination. ${ }^{15}$ The economic power of the RSA rests mainly on three pillars, viz its wealth of strategic raw materials, its advanced industrial technology and thirdly, its relative political stability. The Soweto riots have, however, influenced the political image of the RSA. Political and economic power-bases make it possible to maintain a credible military threat. The opposite is also true, viz that a threatening and credible military posture gives the government of the day the necessary freedom of action. ${ }^{16}$ The SWA question is a classic case where the aforegoing statement is applicable.

\section{Conclusion}

Finally, it must be confirmed that the role of military power has changed. Its use, however, continues to exist, although in another form. Due to cultural values and international politics, military violence is naturally less acceptable as a direct means of coercion, though its value remains as an indirect form of coercion. Particularly in Southern Africa, a permanent show of force (without provocation) is extremely necessary in order to support the other elements of national strategy. ${ }^{17}$ The psychological dimension of strategy must not be lost sight of in a world in which military violence is regarded as an extreme form of coercion. In the latter respect the RSA must propagate its power-bases subtly by means of an indirect strategy. Thoughtless and blatant forms of coercion in particular, or disregard of the 'brinkmanship' principle, may be counterproductive for South Africa.

\section{Conceptional background}

1. At first glance it would seem that the subject covers a wide field. Although military power forms a very significant component of the total strategy, that is the coercive means available to a state, its strategic scope is relatively minor as against the sum total of all available means! By way of introduction therefore this is a brief orientation to strategy, its scope and progress in world politics specifically with reference to the coercive means of military power. (This paragraph should be read together with the introduction).

2. Although many definitions of the three various levels of strategy exist, viz total, general and operational strategy, the points of view expressed here are derived from the thinkers in the RSA. The Defence Force (Departmental) Strategy and the SA Army Basic Doctrine are at present being developed and revised. The writer appreciates that this development and revision is an all-embracing task. In the light of this and for the sake of a uniform method of approach, this essay has been provided with a comprehensive introduction. The perceptive reader will discern that, for the sake of orientation, this is an essential prerequisite before a study of this nature and scope can be approached analytically, critically and objectively. It is only in this manner that a significant contribution can be made towards this important field of study. The essential elements of the concept total strategy boil down to the fact that:

a. A conflict situation exists between governments and/or interest groups.

b. All available means towards coercion or settlement of the conflict shall be applied in an effort to achieve a favourable situation.

c. An attempt shall be made to achieve the objectives of the foreign policy of a state.

The other definitions in the hierarchy of strategy can be reduced to the aim of total strategy, namely to achieve the objectives of its foreign policy. Furthermore it continues to point towards the use of means of coercion to resolve the conflict situation advantageously.

3. The classical means of coercion has changed from armed violence to less destructive and useful instruments, mainly on account of the appearance of nuclear arms on this scene. These means are seen in the present juncture as being economic, political, diplomatic as well as military. An additional dimension regarded as important by philosophers on strategy, is the psychological modus operandi. This method has particularly been emphasised by militarists and philosophers on militarism. Particular reference must be made to the contribution of Gen André Beaufré the concept of indirect strategy. Abovementioned thinker also perceived an analogy 
between the so-called 'cold-war' of the communist bloc and the indirect modus of total strategy. Application of military power plays a much bigger part in direct strategy.

4. The question arises: 'What is regarded as military power?' The fundamental difference between military power and military force is that it is synonymous with 'deterrence' in contrast with 'violence'. This implies that the physical employment of military power boils down to the application of military force (violence). The power to cause damage is more pliable than force itself. Certain characteristic factors exist, though, that have to manifest the credibility of deterrence, namely the potential of the military power, the value attached to it and the skill to transform the application of military power into force.

5. The international community of nations has been characterised by mutual conflicts. Strategy is more than merely the operational concept of foreign-orientated state action; international politics is determined inter alia by the external policy in a field where conflicts often exist in opposing expressions of will. The hierarchy of state policy can be viewed as national interests and aspirations at the top of the pyramid, followed by objectives, goals and policy. Policy, therefore, is based on the preconceived concepts of national interest. As previously stated the aim of strategy is to achieve the objectives of the foreign policy of a state.

6. The bipolar balance of power of the two Superpowers (USA and USSR) lasted until approximately 1956. In the second half of the fifties international politics once more moved in the direction of a political multipolar commonwealth of nations. After the Second World War the Marshall plan economically assisted a devastated Europe and established Japan as an industrial country. During that same time the main industrial countries established a new economic order which was founded on the Tariff and Commercial Agreement, the International Monetary Fund and the World Bank. The European capitalistic countries followed up this initiative with the European Economic Community, in an endeavour to accomplish economic unity in Europe. These 'new orders' were particularly directed towards economic interdependence. The spectacular results of Japan and West Germany were inter alia products of these initiatives. The post-war years were furthermore characterised by a so-called transformation in international politics on account of the arms technology; this led to nuclear weapons and the modernisation "of secular changes in the structure of society.' At this stage the awakening of the Third World needs a brief mention. The decolonisation process had already started in the fifties. The process during the sixties, and subsequently, was in the form of so-called wars of liberation. The Superpowers zealously competed for the favours of the newly independent states; the inducements were primarily the availability of raw products and minerals.

7. At the present juncture there is a clear distinction between major, medium and minor powers according to economic, military and political criteria. The minor powers of the Far East and Africa were initially regarded as underdeveloped, but currently, in terms of economic capability, they are described as 'Less Developed Countries (LDCs)'. As a result of this so-called shift in emphasis from the concentration on the maintenance of law and order to the management of the economy, the Third World has developed greater bargaining powers or means of bargaining. Here we think in particular of the strategy of the OPEC countries since 1973. This strategy again gave rise to a deterioration of the economies of the Third World. However, these countries accused the capitalist countries of exploiting the poor and impeding their legitimate development. Consequently, these 'LDCs' made a series of unexpected demands for trading concessions and economic aid. These demands were designed to instil in the Western Nations a feeling of guilt as a type of 'sentiment', in order to obtain improved bargaining power. In the absence of other power-bases the undeveloped countries were obviously, in so far as the foregoing was concerned, employing a kind of moral lever.

8. The so-called aid by the USSR to the Third World has primarily the provision of weapons. As a result of the so-called 'Low Politics', violence shifted from the international to the domestic level. It became increasingly easier for the 'LDC' to play host to revolutionary interest groups; here one thinks especially of the particular set-up in Southern Africa. Zambia and Mozambique accommodated the two wings of the Anti-Rhodesian Patriotic Front, whilst Angola continue to look after the 'interests' of SWAPO

\footnotetext{
- Col A van Driel, SA St Corps (Army), Hons (BA) Strategic Studies.

- The above article has already been written before Dec 1980 in view of the Military Essay Contest of 1980, at the conclusion of which it
} 
was honourably mentioned. It was originally written in Afrikaans, but was translated into English by the Author.

\section{FOOT NOTES}

1. The 'INTRODUCTION' and Conceptional Background should be read together.

2. Although Clausewitz supported the 'idea of absolute war' prior to 1804 , it has to be seen against the background of the Napoleonic era (1792-1815). Already in 1804 Clausewitz's ideas underwent a change when he distinguished between wars of annihilation and 'wars to break the will of the opponent'. Thereafter he theorised still further about the above-mentioned two types of war: nevertheless he urged until the end of his works that violence is and remains the 'dominating idea' even in a limited war for limited objectives.

3. Genghis Khan (1162-1227) was a Mongolian chief and a born ruler. He strove for the unification of the Tartar and Mongolian tribes. In 1215 he subjugated China by leading a charge against Peking, which also involved extreme deeds of plundering and other atrocities. In 1218 he invaded Turkestan with approximately 750000 soldiers. By 1227 the area from the Pacific Ocean to the Dnieper River was under his control.

4. By 'threatening' in this context is meant that military force should serve as a credible deterrent (means). Deterrence is explained in par 19 infra.

5. In reality the art of 'political audacity' is not to plunge downwards over the brink in the chaos of violence.

6. The creating of a feeling of uncertainty with the opponent is an important factor so that he never knows precisely what reaction to expect. Uncertainty involves, inter alia, lack of control of a conflict situation by any actor, as well as the unpredictability of the expected action by the opponent.

7. 'Die Republiek beskik oor die wil en die vermoë om sy vyande die stryd aan te sê.' (A quote from a paper delivered by Chief of the SADF at the Potchefstroom University on 21 August 1981 at a Symposium 'Terrorisme - Die Strydmetode van ons Tyd').

8. The misconception of a so-called 'absolute war' has already been explained in foot-note two.

9. The now already well-known 'Lancaster House Agreement' of Dec 1979 brought about a political settlement of some kind in Rhodesia, now Zimbabwe.

10. The significance of this is implicity and explicitly stressed in Prof Mike Louw's article.

11. The importance of the RSA's strategic minerals has again been highlighted by $\mathrm{Dr}$ Tom Muller in the edition of Rapport on $3 \mathrm{Feb} 80$.

12. Since the Iranian revolution (1979), the USA and Britain have decided on the joint development of the naval base at Diego Garcia. If the amount of R150 million, as quoted in news reports, is correct, it appears that the undertaking is not particularly significant. The argument is raised, inter alia, that Diego Garcia is too far from the Middle-East conflict areas. The alternative of drifting task forces on flotillas and aircraft-carriers is employed by the USA - but these the Russians would regard as 'sitting ducks'.

13. According to the Petrick report (1970), the RSA's coal supply was fixed at 25000 million tons of economically recoverable coal reserves. At present these reserves are much more. In 1978 only eight per cent of the total coal consumption (of that particular calendar year) was used for the petrol/chemical industries (including SASOL). With coal exports to Japan, this is, next to the gold, the most important earner of foreign exchange.

14. This quotation was used by the Honourable Prime Minister and Minister of National Intelligence during a lecture at the Defence College.

15. The Prime Minister's twelve-point plan and the resultant idea of constellation as well as the Southern African Development Bank, open up new horizons. Apart from this, it is expected that the constitutional changes, such as the President's Council, will satisfy the political aspirations of other population groups within the RSA.

16. In General C. L. Viljoen's Paper as quoted in footnote seven, this point is reiterated: 'Militêre optrede het as hoofdoel die skep van' $n$ veiligheidsambreel wat die staatsgesag genoeg vryheid van optrede bied om sy staatkundige program ten uitvoer te bring.'

17. Within the constellation context, security objectives and a strategy for Southern Africa will in course of time have to be planned and implemented on a regional basis.

\section{BIBLIOGRAPHY}

1. Van der Waals, W. S.: Totale Strategie - Direk en Indirek (SA Army College Prècis SD/12/1/19 (BS), Oct 78)

2. Fourie, D. F. S.: Introduction to Strategy (UNISA Study Guide NO 2 for Strategic Studies, 1978).

3. Schelling T. C.: Arms and Influence, Yale University Press 1976.

4. Knorr, K.: On the Use of Military Power in the Nuclear Age. Princeton University Press, New Jersey, 1966.

5. Trager, F. N. (Hoofred) : Economic Issues and National Security. The Regents Press, Kansas, 1977.

6. Weltman, J. J.: On the Obsolescence of War (International Studies Quarterly, Dec 74).

7. Buchan, A.: War in Modern Society. Watts and Costs, London, 1966.

8. Holsti, K. J.: International Politics - A framework for Analysis (Second ed). Prentice Hall International, London, 1974.

9. Brodie, B.: Strategy in the Missile age. Princeton University Press, New Jersey, 1965.

10. Hartman, F. H.: The Relations of Nations (fourth ed) Macmillan Publishing Co, New York, 1973.

11. Malan, M. A. de M. (Genl The Honourable Minister of Defence) : Die Militêre Weerbaarheid van die RSA in die Huidige Tydsgewrig (Symposium at P.U. vir CHO on Strategic Aspects of the Present World Politics, 1975).

12. Baylis, J., et al : Contemporary Strategy - Theories and Policies. Croom Helm, London, 1975.

13. Hoffman, S.: The Acceptability of Military Force (Adelphi Paper No $102,1973)$.

14. Martin, L.: The Utility of Military Force (Adelphi Paper No 102 , 1973).

15. Fuller, J. F. C.: The Conduct of War : 1789-1961. Eyre Methuen London, 1972 (University Paperback Edition).

16. Huntington, S. P.: Changing Patterns of Military Politics. The free Press of Glencoe, Columbia, 1962

17. Osgood, R. E.: Limited War - The Challenge to American Strategy. University of Chicago Press, Chicago 1957.

18. Kissinger, H.: Necessity for Choice, Chatto and Windus, London, 1960.

19. Louw, M. H. H.: Die Strategiese Rol van Afrika in Wêreldverband (Bulletin for Africa Institute, Aug 78). 